\title{
Discursive Construction of a Destination. Urban Transition Through Tourism in Ticino Between 1980s and 2010s
}

Construction discursive d'une destination. La transition urbaine par le tourisme au Tessin entre les années 1980 et 2010

\section{Mosè Cometta and Mathis Stock}

\section{OpenEdition \\ Journals}

\section{Electronic version}

URL: https://journals.openedition.org/tourisme/3620

DOI: $10.4000 /$ tourisme.3620

ISSN: 2492-7503

Publisher

Association Mondes du tourisme

\section{Electronic reference}

Mosè Cometta and Mathis Stock, "Discursive Construction of a Destination. Urban Transition Through Tourism in Ticino Between 1980s and 2010s", Mondes du Tourisme [Online], 19 | 2021, Online since 15 September 2021, connection on 17 September 2021. URL: http://journals.openedition.org/tourisme/ 3620 ; DOI: https://doi.org/10.4000/tourisme.3620

This text was automatically generated on 17 September 2021.

\section{c)}

Mondes du tourisme est mis à disposition selon les termes de la licence Creative Commons Attribution - Pas d'Utilisation Commerciale - Pas de Modification 4.0 International. 


\section{Discursive Construction of a Destination. Urban Transition Through Tourism in Ticino Between 1980s and 2010s}

Construction discursive d'une destination. La transition urbaine par le tourisme au Tessin entre les années 1980 et 2010

Mosè Cometta and Mathis Stock

\section{AUTHOR'S NOTE}

This work was supported by the Swiss National Science Foundation under Grant POLAP1-172054/1.

\section{Introduction}

1 "Planetary urbanisation" (Lefebvre, 1970; Brenner and Schmid, 2014) is a major contemporary issue for human societies due to the ever-changing geographical conditions of inhabiting. In a capitalistic accumulation regime, planetary urbanisation can, therefore, be understood as a "production of space", with the urban characteristics expanding beyond the city and reorganising the urban at different levels, from the local to the global (Lefebvre, 1970, 2001; Soja, 1996; Brenner and Schmid, 2014). Tourism plays a key role in these urbanisation processes, due to its ever-expanding importance: the emergence of seaside resorts and mountain resorts over the last 200 years, as well as the re-urbanisation of cities through tourism, are cases in point (Stock and Lucas, 2012). As international arrivals increase - from 25 million international arrivals in 1950 to 1.4 billion in 2018 (UNWTO, 2020) - and domestic tourism grows even more, probably attaining a tenfold figure - China with its 4 billion 
trips, or the USA with its 2 billion trips, are cases in point on a national level (UNWTO, 2020) - new urban infrastructure, as well as new way of governance are needed, concretising the link between the growing touristification of the world and its urbanisation.

2 Ticino, the southern Italian-speaking canton of Switzerland, is part of these dynamics and we use this case to demonstrate how, through the discursive construction of a region as a tourist destination, we can study the institutional understanding of urban reality. Consequently, we focus on the Cantonal Tourism Organisation's (called Ente Ticinese per il Turismo, from here onward the ETT) conception of tourism. Founded in 1972 - amid a series of failed attempts to organise management and planning institutions on a cantonal scale (Ceschi and Ghiringhelli, 1998) - the ETT was the public actor in charge of the coordination of promotional campaigns and other organisational tasks until 2014 when the public-private ATT (Ticino Tourism Agency) took over. As the public organisation called to coordinate and manage the overall tourism policy, the ETT was a key actor in the canton's urban and discursive development.

We are thus concerned to understand how tourism authorities conceive their role and their relationship with Ticino. We ask the following questions: From which perspective is tourism considered and to which interests does it correspond? Which territorial and urban discourses have ETT developed over the years? By focussing on the discourse of the ETT, we are able to show a drastic change from the 80 s to the 2010s, from a Keynesian and political conception of tourism to a neoliberal and merely economic one. Our research results show that where tourism management was conceived as a means of social and territorial development, it is now understood solely as a hotel sector lobby.

\section{Theoretical framework}

4 Our research relies on three distinct bodies of work, which will provide the theoretical framework. First, the move towards "thinking through tourism", which differs from thinking about tourism as an object or a mere economic sector, is an important evolution in tourism studies (Scott and Selwyn, 2010). As a relational problem, for instance as a "tourist gaze" (Urry, 1990), a "tourist attraction" (MacCannell, 1999) or a "tourist agency" (MacCannell, 2001), tourism is conceived as a relationship with the world based on the combination of mobility, otherness and recreation. The precise meaning of the phrase "anything is potentially an attraction" (MacCannell, 1999, p. 192) is that tourism is a relational problem that underlines the relationship between imagination and materiality. Instead of theorising tourism as an object in itself, our aim is to understand society's ongoing social, economic, cultural and urban transformations from the perspective of tourism (Equipe MIT, 2002). This perspective allows for thinking about society by analysing the multiple manifestations of the "touristic" (Darbellay and Stock, 2012), for instance issues of co-inhabiting between differently mobile people in contemporary European cities (Füller and Michel, 2014; GravariBarbas and Guinand, 2017; Stock, 2019), or urbanisation processes in Alpine resorts (Stock et al., 2014). In this respect, we dwell on the idea of tourism as an indicator for broader social and cultural change and will show how tourism is related to urbanisation processes through the example of Ticino. 
Second, a critical understanding of tourism's links with capital accumulation is necessary. As Britton (1991) showed, tourism development is related to the capitalist structure of economy and can therefore be seen as a field of struggle between different actors with opposing class interests. Important debates on the neoliberal mode of capitalism regulation and regimes of capital accumulation (Foucault, 2008; Aglietta, 1979; Boyer, 1990) emphasise the regulation of capitalism and its various regional forms. Coles (2003), Hoffman et al. (2003) and, more recently, Marie dit Chirot (2018) explored tourism in this respect, showing that neoliberal organisation makes a difference by regulating tourism in a different way from Keynesian forms of regulation. Agarwal (2002) examines the regulation of capitalism in seaside resort development as "restructuring", whereas Hawkins and Mann (2007) show that the World Bank has fostered tourism projects since the 1960 s as a modernisation of the economy and society. The point is, therefore, to place destinations strategically in a "global tourism field" (Stock et al., 2014) where they engage their "symbolic capital" (Harvey, 2001) in a process that leads from one form of capitalist regulation - Keynesianism - to another neoliberalism.

6 Third, following Lefebvre (1970), Lévy (1994) and Stock and Lucas (2012), we understand the urban as a social space defined by density, diversity, centrality and public space. In this perspective, not just cities but any geographical place can be analysed as urban, albeit with different degrees of urbaneness or urbanity (Lévy, 2012). "Urbanisation" means, therefore, the emergence or complexification of the urban, be it in cities or other territorial forms. Tourism is one of the vectors through which this production of space is carried out in a capitalist society and can be seen as an example of capitalism's "spatial fix" (Harvey, 2001, 2008) triggering urbanisation. Lefebvre $(2000$, p. 152) recognises that "the leisure industry combines with the construction industry to extend cities and urbanisation along coasts and in mountainous areas". The perspective adopted here frames tourism as a contribution to urbanisation processes: urbanisation through tourism is therefore at stake. This can be linked to different contributions in the literature: as recently shown for Montreux (Humair et al., 2014), but also for British seaside resorts (Williams and Shaw, 2004); service, amenities and technologies are regarded as the key drivers of urbanisation processes. There also has been the transformation from non-built to built space and in population growth (Walton, 1983; Soane, 1993). Through the growth of services, labour markets and in resident diversity, the quality of places has been transformed from rural into urban. This has been framed by Mullins (1991, p. 332) as "tourism urbanisation as a new spatial form". More recently, Stock and Lucas (2012) develop the idea of a "double urban revolution of tourism" triggered at seaside resorts and in cities. It means especially the transfer of urbanness from the city to the resort, but also the global centralities developed by tourism in cities. Herrera et al. (2007) link this urbanisation through tourism to urban development plans which effectively allow the spatial fix of tourism through urbanisation and its gentrification consequences.

7 In order to mobilise this framework for Ticino, we suggest that tourism is a key sector in the production of urban space, and it was understood by public institutions as a particularly relevant sector during the urban transformation that has taken place since the second half of $20^{\text {th }}$ century. Our endeavour is to understand the way in which the tourism authorities conceived their function in the leading tourism sector. This reconstruction of how institutions have understood their role in these processes seems 
justified in order to bring more insights on the balance of power within a given society. From this perspective, discursive evolution shows a deeper evolution of the rationality, which is the result of a particular perspective's hegemony over a cultural panorama (Gramsci, 2011). The way authorities understand the relation between tourism and society is, therefore, fundamental for a critical understanding of their goals and for contextualising their actions. Thus, we analyse the data through our theoretical framework: tourism discourses are interpreted by a perspective of tourism as a social practice, as an important economic sector and as an important actor in organizing space.

\section{Spatial context: Ticino in an urbanisation process through tourism}

Ticino is the most southerly canton of Switzerland. It is the only entirely italophone canton, therefore a national minority within the Swiss Confederation. More than $60 \%$ of its borders are touching Italy. Ticino is the only Swiss canton to be close to a foreign metropolis (Milan is at less than $40 \mathrm{~km}$ away). Thus, it also provides an interesting case of tourism in borderland regions (Saarinen and Kask, 2008).

\subsection{Urbanisation of Ticino}

For centuries, Ticino was divided into eight colonial departments under the control of German-speaking cantons. Its geographical position makes it a very important crossing point over the Alps, which gives direct access to the Po valley in Italy and Milan. Its mountainous territory, the scarcity of arable land and the administrative divisions led Ticino to being underdeveloped and characterised by subsistence agriculture and migration (Ceschi, 1998). The cantonal unit was imposed at the beginning of the $19^{\text {th }}$ century, giving rise to a weak and unprepared state administration (Ghiringhelli, 1998). The parochial rural mentality was fundamentally hostile to the central authorities (Diener et al., 2006). After World War II, the population became better-off, which transformed the society and the territory quickly and radically from a rural society to an urban one. Currently, more than $80 \%$ of Ticino inhabitants live in an urban agglomeration (RCT, 2009, p. 36), and its most economically developed areas form a network of cities with neighbouring Italy (Diener et al., 2006, p. 129) (fig. 1). As global urban competitiveness is thought to be increasing, cantonal planning policy is pushing for a stronger collaboration with the neighbouring Italian cities. Moreover, the quasi doubling of the housing stock between 1947 and 1970 (Caccia, 1984) and the authorities regarding Ticino as an urban society in their 1980s and 2010s planning politics (RCT, 1990, 2009) are in line with urbanisation processes. 
Figure 1. The transnational urban network of Ticino

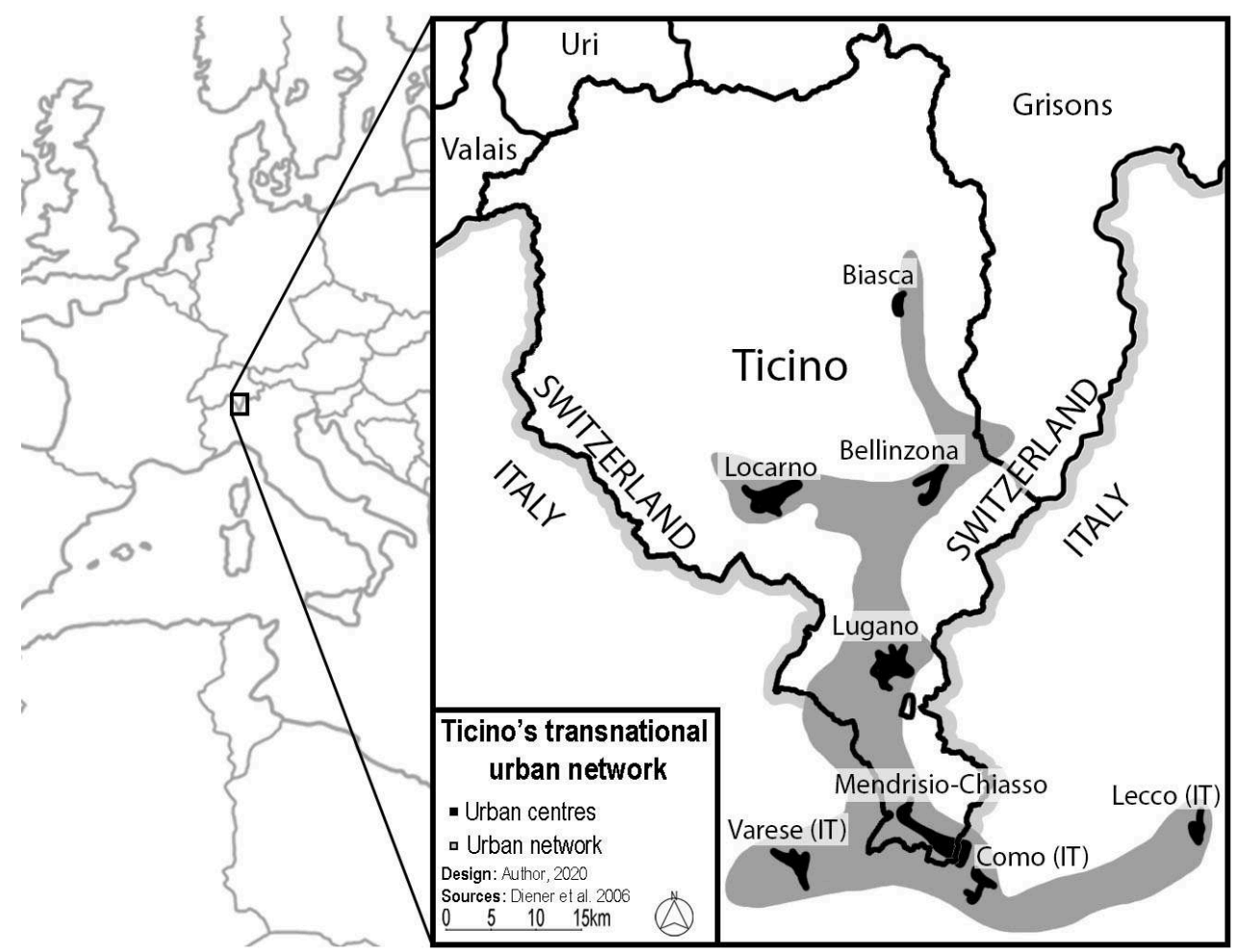

Source: Figure adapted by authors after data from Diener et al., 2006

Figure 2. Spatial differentiation between urban centres and rural areas in Ticino

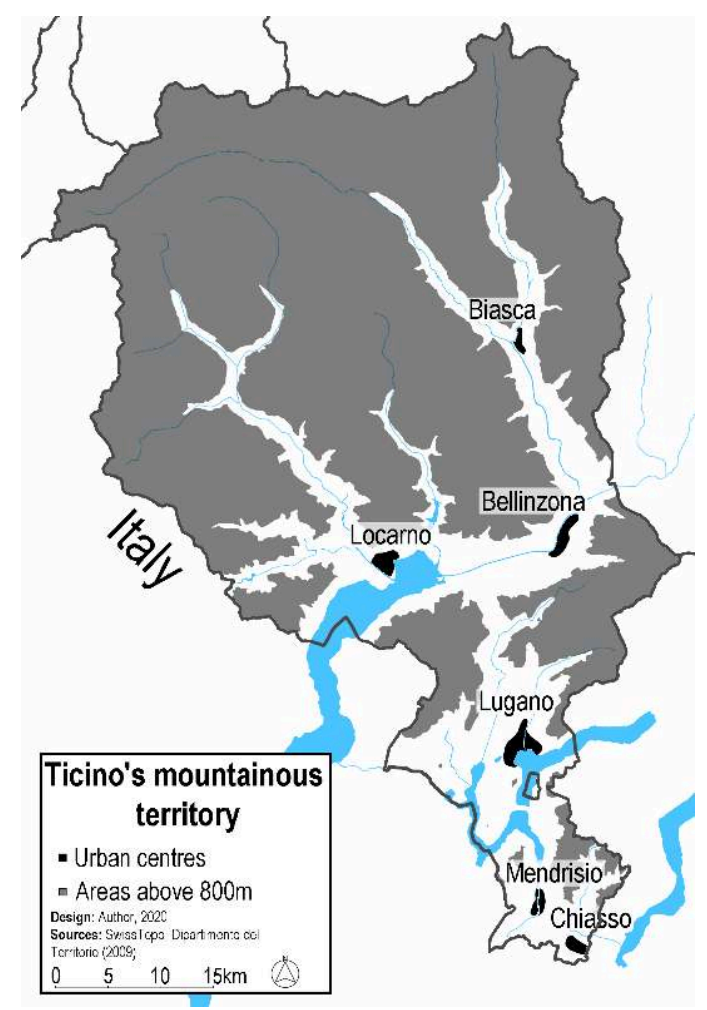

Source: Authors 
From a physical point of view, Ticino has two types of territory: the alpine valleys or mountainous areas on the one side, the lacustrine and hilly areas on the other (fig. 2). The advent of urban society has amplified the differences between these two territories. Scattered and growing settlements increasingly occupied the valley floors and the flat areas, while the peripheral valleys suffered a permanent demographic and economic recession. The scarcity of available land for urban development should be noted. This increases competition and struggle for place and territory between the different actors.

\subsection{Tourism development in Ticino}

Historians date the emergence of tourism in Switzerland since the $18^{\text {th }}$ century with the purpose of an ideal reconnection with nature (Tissot, 2000). Distancing themselves from the city's frenzy, aristocrats and the bourgeois went looking for glaciers, alpinism, landscapes and clean air in an uncontaminated rural context (Equipe MIT, 2005). Nevertheless, the emergence of alpine resorts can be understood as an urbanisation process: new infrastructures were needed to fulfil tourists' desires (Stock and Lucas, 2012; Humair et al., 2014). The ideal of reconciliation with nature was, therefore, one of the most relevant causes of the urbanisation of peripheral areas such as the alpine valleys. This process grew in importance when the middle and working classes started adding to the number of tourists gathering in the Swiss Alps for their summer and/or winter holidays.

In Ticino, tourism followed a similar process, driven particularly by domestic tourism, especially from the German-speaking parts. The latter imagined the peace and serenity of Ticino's people, whom they considered Latin or even Mediterranean, simple and uncontaminated (A7; A8). The socio-cultural stereotypes were therefore one of the fundamental vectors of the early tourism in the canton, which the local population experienced as a sort of servitude to rich guests, therefore, fuelling tensions related to issues of dealing with otherness. At the same time, the industry's economic importance was seen as an element of "modernisation" of Ticino, stimulating the emergence of urbanisation processes since the 1950s. Marco Solari, Director of the ETT between 1972 and 1991, believed that "it is tourism, whether one wants to admit it or not, which contributed to Ticino emerging from the dark ages" (A6) and stressed the importance of tourism as an urbanising and modernising factor.

13 Tourism is a relevant element in the Ticino economy. In 2014, tourism created more than 20,000 full-time jobs, contributed $9.6 \%$ to the cantonal GDP and generated more than $12 \%$ to employment (Medici et al., 2014, p. 97). 


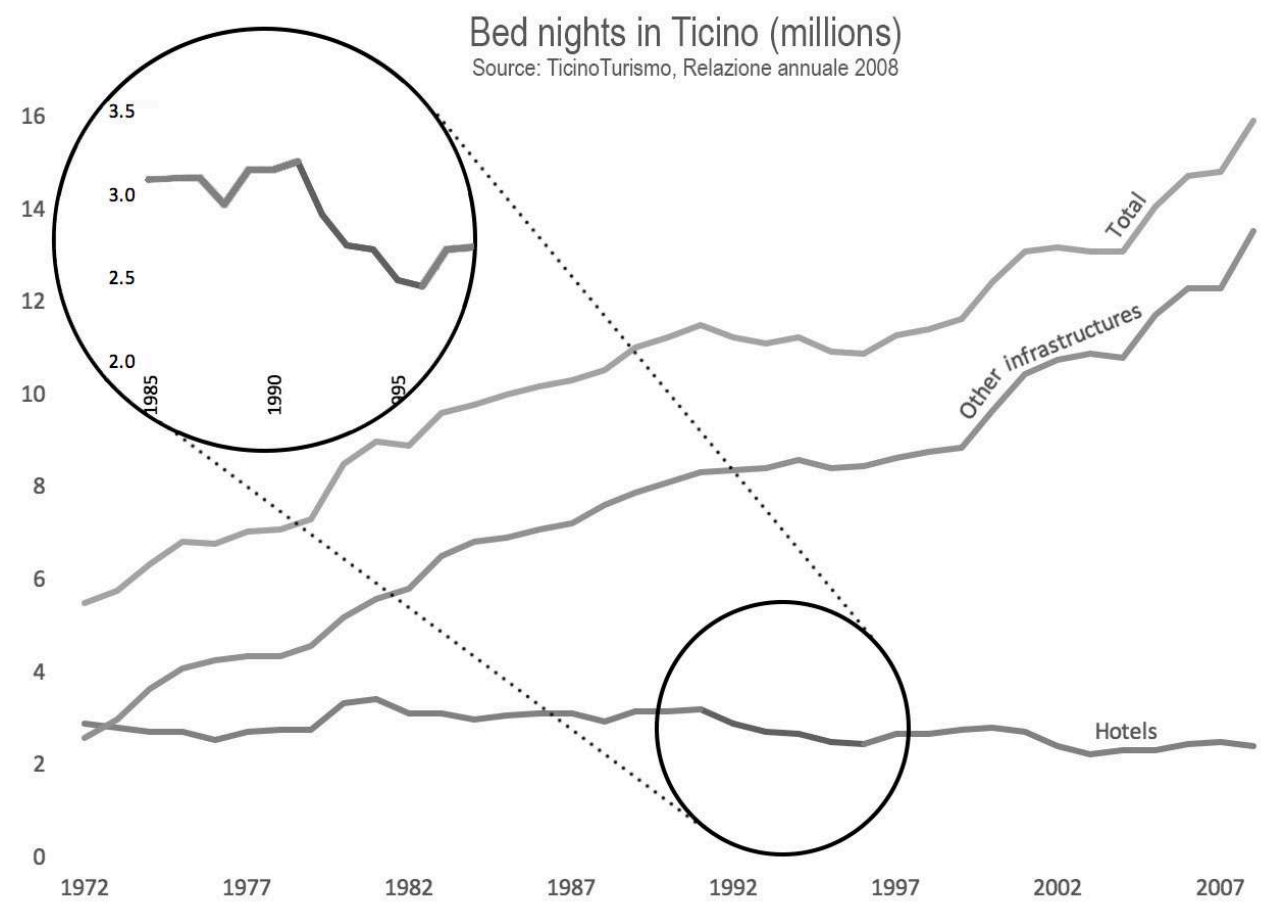

Source: Authors (after data from Ticino Tourism)

However, the tourism development has been two-fold: since the 1980s, Ticino hotel bed nights have decreased from 3.3 million to 2.4 million. During the same period, bed nights in rented homes and apartments have increased from 5.2 million to 13.5 million (fig. 3). The crisis in the hotel sector is highlighted in the enlargement. The graph shows that rented homes, apartments and camping sites are overtaking the hotel sector. We also observe a reform of local tourism organisations, leading to a geographical restructuring of destinations: the period 1972-2014 saw a radical process of centralisation (fig. 4), where destinations are constructed around the urban cores of Lugano, Bellinzona, Mendrisio-Chiasso and Locarno, following Ticino's urban evolution. This evolution shows how economic efficiency has become more important than local representativeness in tourism management. It also shows the link between urbanisation processes and the evolution of tourism management via a centralisation process. A new geographicity of administration and management arises, allowing for the invention and construction of flexible destinations. 
Figure 4. The process of centralisation of local tourism organisations between 1972 and in 2014 in Ticino
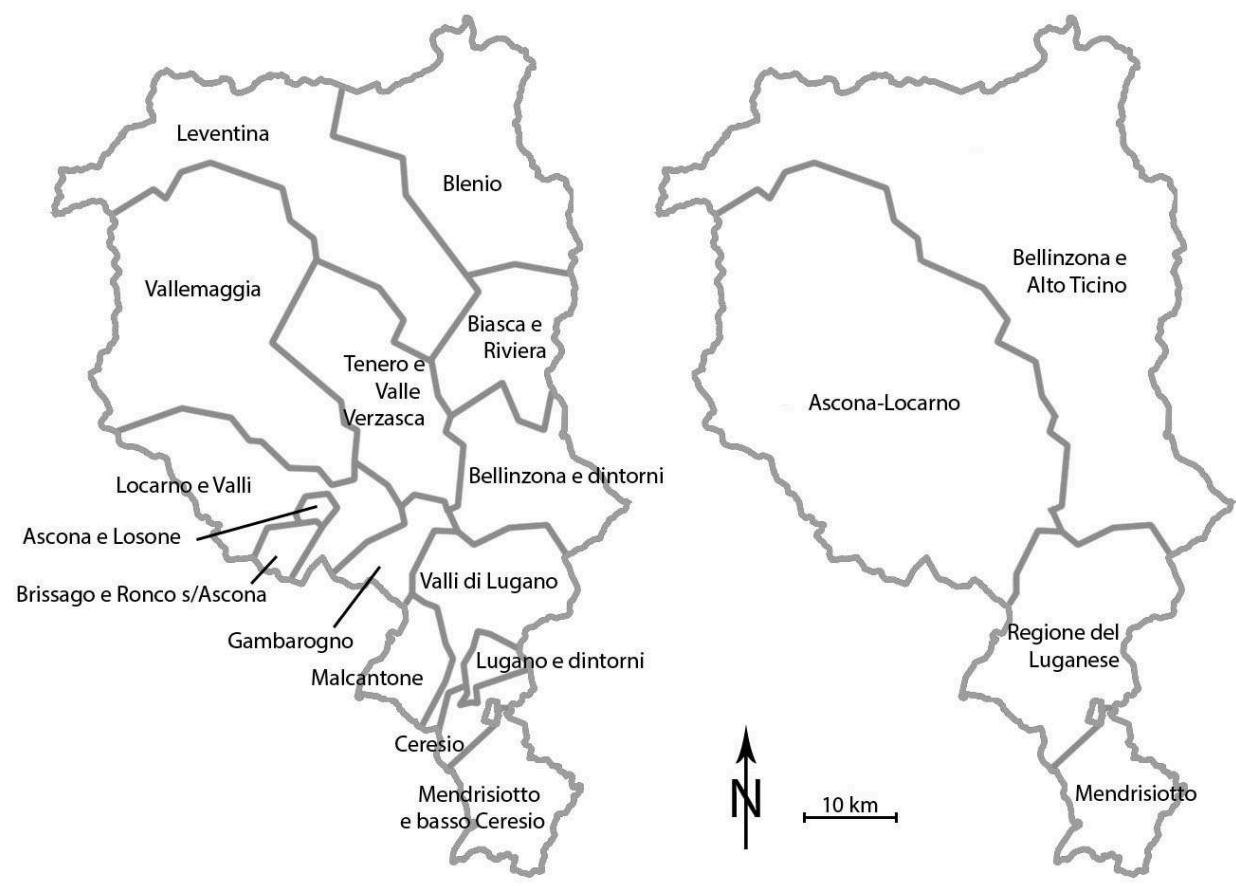

Source: Figure adapted by authors after data from RCT, 1998

\section{Data description and methodology}

A series of annual reports from the ETT are available on the ATT website. The available discourses on this website belong to two categories: the speeches that the director and the President of the Organisation (tab. 1) gave at the two annual assemblies and the brochures reflecting the analysis and the annual data. A total of 795 pages divided into 94 documents were read and coded (tab. 2). All the texts in the archive were analysed, whereas this table lists only those mentioned in this paper.

Table 1. ETT presidency over the years

\begin{tabular}{|l|l|l|}
\hline Year & President & Political affiliation \\
\hline 1980-1984 & Flavio Cotti & $\begin{array}{l}\text { Christian Democratic People's Party of Switzerland, conservative } \\
\text { cantonal minister }\end{array}$ \\
\hline 1984-1991 & Renzo Respini & $\begin{array}{l}\text { Christian Democratic People's Party of Switzerland, conservative } \\
\text { cantonal minister }\end{array}$ \\
\hline $1992-1994$ & Dick Marty & Free Democratic Party of Switzerland, radical MP \\
\hline $1996-1998$ & Marco Solari & None \\
\hline
\end{tabular}




\begin{tabular}{|l|l|l|}
\hline 1999-2006 & $\begin{array}{l}\text { Marina } \\
\text { Masoni }\end{array}$ & Free Democratic Party of Switzerland, neoliberal cantonal minister \\
\hline 2007-2014 & Marco Solari & None \\
\hline
\end{tabular}

Source: Authors

The organisation made an explicit effort to summarise its history, which could provide insight into its self-perception of its role in Ticino's development. There are important limits to the data that we accessed, of which the documents' heterogeneity is the most relevant. The differences between brochures and speech transcripts need to be taken into account.

Table 2. The text cited from ETT archive

\begin{tabular}{|c|c|}
\hline Code & Reference \\
\hline A1 & F. Cotti, Relazione del Presidente all'Assemblea, 25 June 1980. \\
\hline A2 & M. Solari, Relazione del Direttore all'Assemblea, 23 December 1980. \\
\hline A3 & F. Cotti, Relazione del Presidente all'Assemblea, 02 June 1981. \\
\hline A4 & M. Solari, Relazione del Direttore all'Assemblea, 02 June 1981. \\
\hline A5 & F. Cotti, Relazione del Presidente all'Assemblea, 05 July 1982. \\
\hline A6 & M. Solari, Relazione del Direttore all'Assemblea, 05 July 1982. \\
\hline A7 & F. Cotti, Relazione del Presidente all'Assemblea, 10 June 1983. \\
\hline A8 & M. Solari, Relazione del Direttore all'Assemblea, 16 December 1983. \\
\hline A9 & R. Respini, Introduzione, 1984. \\
\hline A10 & Ente Ticinese per il Turismo, Piano direttore cantonale e turismo, 1984. \\
\hline A11 & R. Respini, Relazione del Presidente all'Assemblea, 17 June 1985. \\
\hline A12 & R. Respini, Relazione del Presidente all'Assemblea, 27 June 1986. \\
\hline A13 & R. Respini, Relazione del Presidente all'Assemblea, 11 June 1987. \\
\hline A14 & R. Respini, Relazione del Presidente all'Assemblea, 30 June 1988. \\
\hline A15 & M. Solari, Relazione del Direttore all'Assemblea, 16 December 1988. \\
\hline B1 & Ente Ticinese per il Turismo, Relazione Annuale. Commento generale, 1994. \\
\hline B2 & S. Grandini, Considerazioni sulla stagione 1995. Note introduttive, 1995. \\
\hline B3 & S. Valli, Considerazioni sulla stagione 1996. Note introduttive, 1996. \\
\hline
\end{tabular}




\begin{tabular}{|l|l|}
\hline B4 & G. Stinca, Relazione annuale. Commento generale, 2000. \\
\hline B5 & M. Masoni, Relazione Annuale. Note introduttive, 2002. \\
\hline B6 & Ente Ticinese per il Turismo, Relazione Annuale 2011. Enjoy Switzerland Ticino, 2011. \\
\hline B7 & Ente Ticinese per il Turismo, Relazione Annuale 2012, 2012. \\
\hline
\end{tabular}

Source: https://www.ticino.ch/it/about-us/ett-storico?utm_source=ticino.ch\&utm_medium=shorturl; Authors.

Discourses are a central element of contemporary society (Fairclough, 2001). Through them, representations of facts and social actors are constructed. A critical analysis of those discourses is, therefore, important to better understand social reality (Taylor, 2004). In this paper we focused on showing the evolution of ETT institutional discourses. We have followed an approach close to discourse and content analysis (Talib and Fitzgerald, 2018; Hajer, 2003; Kohlbacher, 2006) in order to hierarchise, select and order the different issues. Documents were coded and analysed using Atlas.Ti software. To comply with our theoretical framework - understanding tourism as a social practice, as a fundamental economic sector and as an important spatial actor - we have focused on the question of spatial justice, that is, how to manage and distribute tourist flows and projects in different territories aiming for equitable development. This should bring further insights into the evolution of institutional rationality, making it clear how tourism organisation positioned itself.

\section{Results: from spatial justice to a mere economic understanding of tourism}

During the 1980s, the ETT leadership was deeply interested in the urban development of the canton. The ETT was, therefore, an important actor in the debates on what could be called "spatial justice" (Soja, 1996). Nevertheless, this vision gradually evolved towards a mere economic understanding of tourism (tab. 3).

Table 3. The subdivision of the ETT discourses since the 1980s

\begin{tabular}{|c|c|c|c|}
\hline Theme & Sub-themes & 1980s & 1990-2013 \\
\hline \multirow{3}{*}{$\begin{array}{l}\text { Spatial } \\
\text { justice }\end{array}$} & Rustici & $\begin{array}{l}\text { Rustici (stone-walled, simple rural houses) } \\
\text { used as an element to enrich the peripheral } \\
\text { valleys }\end{array}$ & Disinterest in the issue \\
\hline & $\begin{array}{l}\text { Territorial } \\
\text { balance }\end{array}$ & $\begin{array}{l}\text { The territory must be governed for the } \\
\text { public interest }\end{array}$ & Disinterest in the issue \\
\hline & Second homes & $\begin{array}{l}\text { Second homes damage tourism and the } \\
\text { territory. They must be opposed }\end{array}$ & Disinterest in the issue \\
\hline
\end{tabular}




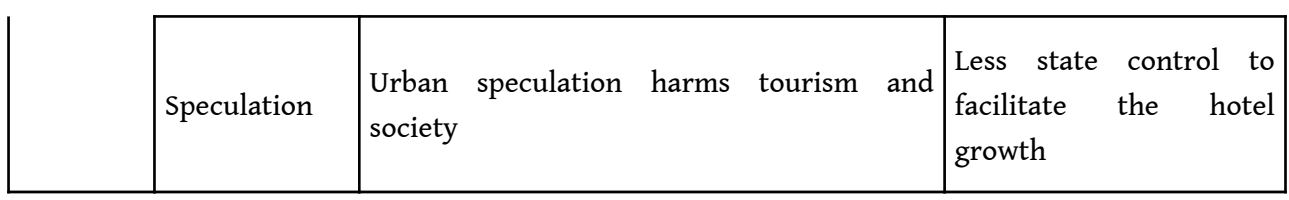

This table helps to show discursive changes toward a full neoliberal perspective.

Source: Authors

\subsection{The rustici issue}

19 Rustici (local stone cottages with granite roofs) are considered among Ticino's most iconic architectural structures. These traces of spontaneous rural architecture comprise a plurality of different forms (Rossi et al., 1979). They are mostly stone-walled, simple houses used as temporary refuges and stables for the semi-nomadic rural population of shepherds and peasants who lived in the valleys (fig. 5). The map shows the three types of rural society that comprised Ticino's pre-20 $0^{\text {th }}$ century territory. The dark grey shows the agricultural society of the hilly territory. The light grey shows the rich pastoral society of the alpine valleys. The dots show the poorer rural society on the steeper mountainous region. In black, the two major lakes. The map displays the regional differences in traditional rural society. These in turn help to understand the large differences in urban and socio-economic development. Rustici were, until the 1940s, one of the main instruments for the anthropization of the steep mountain slopes and a fundamental part of the subsistence agriculture system. The economic growth of the post-World War II period led to agriculture being abandoned and rustici losing their initial function. Today, urban planning issues are significant since more than 20,000 rustici are situated beyond Ticino's constructible zones (Cedro, 2012). This is significant because the Swiss urban and town planning system relies heavily on the principle of urbanisation and housing is possible only in designated zones called "constructible zones", usually in contiguity with already existing urban nodes and defined by the Communes (RCT, 2011, Art. 18). 
Figure 5. Spatial differentiation of the three types of societies: agricultural, pastoral and rural society in pre- $20^{\text {th }}$ century Ticino

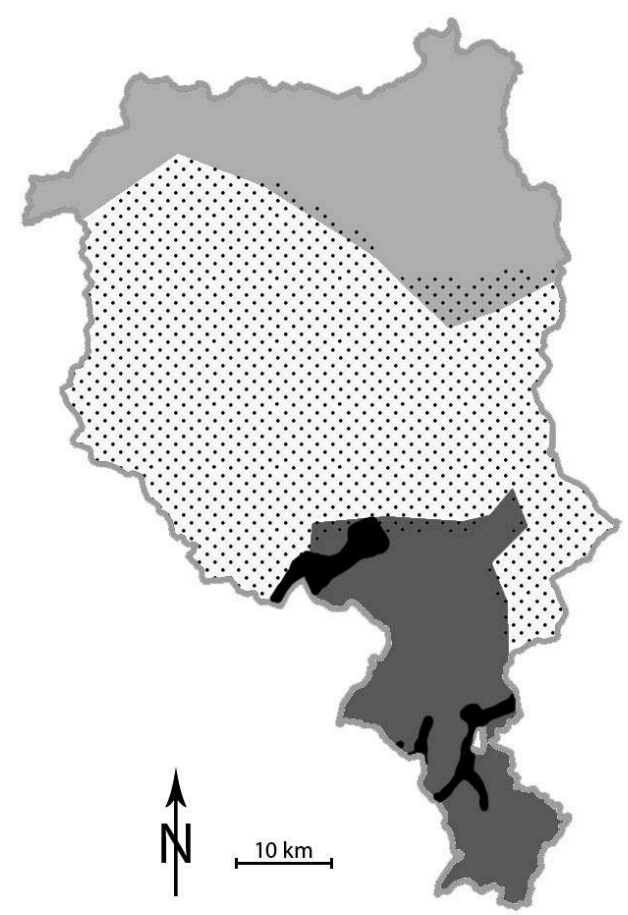

Source: Authors

Rustici were often sold to people from the German-speaking cantons, who were, according to the ETT, "looking for Shangri-la, the mythical land of sweetness and sensual fulfilment" (A2). Architects strongly criticised the transformation of their function from rural to leisure activities (Carloni, 2011; Reichlin and Reinhart, 1979) as a perverse process. During the 1980s, however, ETT was focused on other aspects. Pragmatic political and economic interests drove their approach to the question of transformation, believing that rustici "could be an excellent source of income" (A2). "The owners should know that their properties are an economic asset" (A3). The ETT promoted the transformation of rustici into hotel structures, favouring the rental of those traces of the past and claiming that this could foster rural valleys' economic development. These buildings were "an economic asset that, once lost, cannot be regained" (A3). The transformation of rustici for tourists implied their economic attractiveness, while "avoiding their sale" (A12) and granting the local population control over a tourism infrastructure and over the traces of the old rural civilisation.

21 In the following decades, however, there are no traces of rustici in the discourses analysed. The few times they appear, they are mentioned only as being aesthetically appealing.

\subsection{Mountains, lakesides and territorial balance}

Ticino's territory from a morphological point of view is predominantly mountainous, characterised by two important pre-alpine lakes and some plains (fig. 2). Alpine valleys were from the $16^{\text {th }}$ to the middle of the $20^{\text {th }}$ century the point of departure for 
emigration (Rossi et al., 1979). During the urban transition, those regions have kept declining both demographically and economically. One of the ETT's most important "permanent goals" was that of "allowing the mountainous regions to also benefit from tourism development" (A7) to avoid further economic decay. Tourism was, therefore, envisaged as an instrument for fulfilling non-tourism goals, because it could "guarantee sufficient income for the indigenous population" (A1, 3). The implicit ideal was a balance between tourism centres and the peripheral valleys. "It is necessary to operate in such a way [...] that our valleys are not transformed into a territory that the main tourist centres exploit" (A7). At the same time, this inclusive goal was also meant to protect tourism as a key economic sector: if the poorer Ticino areas were to be "invaded" by tourism that did not contribute revenue (the ETT called this "picnic tourism"), "the valleys' inhabitants' negative reaction would then be planned and inevitable" (A10). The ETT's 1980s goal was, therefore, to organise tourism in such a way that would safeguard the residents from the tourists and tourism from the residents.

In this general struggle for a more balanced spatial development, lakesides were another key element. The ETT's early position was that lakes and urban areas needed to reduce urban speculation, to preserve the public space's quality and accessibility to the lakes, which the lakeshores' growing privatisation was endangering at that time. The ETT aimed to "contribute to the management of the shores by creating lakeside walks and tourist destinations along the coasts" (A1), to "safeguard the banks of lakes and rivers and their accessibility to the public"(A10), and to prevent excessive "privatisation of the lakesides" (A14). This led the ETT to define forms of "good tourism" and "bad tourism". The latter comprised "picnic tourism," as it was argued that this did not contribute substantial revenue to the residents as well as "speculative tourism", which privatises important public spaces and would thus undermine Ticino's balanced tourism and urban development. The ETT, therefore, delineated two categories of tourists: on the one hand, visitors who enjoy their stay in hotels and contribute to the economic growth, while having little spatial impact on the society they visit; on the other hand, visitors who intend to build second houses, taking advantage of their economic power to impose privatisation of the lakeside and of the most beautiful landscapes. The ETT believed that this kind of tourism not only imposed a reduction in the recreational space available for other tourists and the residents - a key goal for their policies (A9) - but also contributed less money to the local economy.

These two ways of practising tourism were regarded as being in opposition. In this confrontation of aspirations, the ETT was clear about which interest should prevail: "from a tourism perspective, we must insist that our most precious property should no longer be sold off" (A6). The ETT believed that one should not mistake speculation for tourism interest, as "tourism is another thing. Tourism means offering a service, certainly not selling off your property, especially the landscape" (A2).

During the 1990s, these types of claims disappeared from the discourses. The renewed ETT directorate terminated its early fight to shape the canton's urban space. Any link to a broader social and political project vanished. The only hint that the ETT's renewed management gave of the different Ticino territories was by stating that overseas tourists "associate Ticino with lakes and mountains" (B7). In this respect, the ETT only mentions the morphological duality from an aesthetic perspective, while the 
differences in the local population's lifestyle and infrastructure needs, as well as "good" and "bad" tourists' different relationships with the environment, are ignored.

\subsection{Second homes}

ETT leaders of the 1980s stated that second homes not only constituted an environmental and political problem, but also a harmful economic reality by being "only occupied a month per year and by generating many expenses for the local communities"(A2). Developing second homes effectively implies important "infrastructural costs that the villages have to bear" (A6), because municipalities are responsible for the infrastructure. Contrary to this tourism of "closed windows second homes occupied just two weeks per year -, Ticino should offer the tourism of human warmth, smile and kindness" (A8).

1980s' ETT narratives provide two main explications of the drawbacks of the second home phenomenon: it not only causes the loss of hotel guests, thus influencing the regional economy negatively, but it also constitutes an important urban development factor led by external actors, resulting in a loss of territorial sovereignty. While central during the first part of 1980s decade, this issue gradually disappeared from speeches.

\subsection{Land speculation}

One of the goals of the 1980s' ETT was to clearly separate tourism and land speculation, thereby reinforcing the positive conception of tourism. Within this framework, tourism was defined as "selling services, not selling off substantial assets" (A1) or the sale of "landscape property" (A2). From the ETT's viewpoint, the speculation not only did not contribute to improving the settlement issue, which led to the image of Ticino as a land of artists and architects disappearing, but it also worsened the livelihood by consuming the little territory that was available. This implies an important "environmental degradation" process (A1; A4; A5). Furthermore, speculation contributed to an increase in land prices. Tourism-driven land speculation meant that rich visitors expelled residents, which in turn generated tension against tourism as a whole. From this perspective, one of the important tasks of the canton authorities was to "defend the landscape and the environment" (A11) by tracing the "limits of the expansion" (A3) and face the "pathological urbanization" (A6) challenging Ticino's reality.

The ETT wanted to "harmonise the governance and the use of the territory by considering the problem of the environmental burden in global terms" (A13). This meant abandoning a strict sectorial view of tourism and understanding it as part of a vaster social and urban phenomenon. In the 1990s, however, this project was abruptly abandoned. During the hotel crisis, the renewed ETT leadership desired "a loosening of norms concerning cartels and restrictive rules on the purchase of housing by foreigners" (B2). The ETT then started opposing the state's goal of regulation, asserting that the canton should encourage economic entrepreneurship and not hinder it, a stance that can be interpreted as a clear neoliberal perspective. It seemed evident to the new leadership of ETT that,

the revival [of the hotel sector] needs a renewal of the offer. This presupposes investments in facilities such as new golf courses, an aqualand, new or refurbished hotels, and so on. We are not asking the state for money. We only ask for leaner, 
less complex and shorter procedures; in short, procedures adapted to modern

times. (B3) and the conception of tourism within society. We can reconstruct the sharp split between the institutional positions defended throughout the 1980s and those of the following decades.

\subsection{Economic growth of peripheral valleys}

1980s ETT narrative on the rustici was concerned about profitability and not about preservation/conservation debates. This suggests that the ETT was focusing on the economic growth of peripheral valleys in an attempt to rebalance the relation between urban and peripheral regions - a perspective clearly linked to the Swiss planning policy of regional equilibrium and de-centralisation (Diener et al., 2006). Tourism was, therefore, understood as an instrument for spreading the urban revolution and economic growth around the canton, leaving no region untouched. This goal of an equal spatial reallocation of tourism income was, however, quickly abandoned at the end of the 1980s. The new management regarded the rustici as only a small part of Ticino's tourism offer, regardless of their historical, social and political meaning. Thus, rustici have ceased to be seen as a resource for the socio-economic development of the population of peripheral areas and, given their low economic importance for the overall tourism sector, have ceased to be an important issue for ETT.

\subsection{Landscape privatisation}

The term «Landschaftsfresser » means literally "Landscape Eater », a term coined by Krippendorff (1977) in order to criticize tourism as devouring the very fundament of what it is based on. Recognising the role that the landscape played in tourism, but also its desire for a better future for the people of Ticino, the ETT could not ignore the land speculation phenomenon. The canton's mountainous territory meant a structural shortage of buildable land (fig. 2), since "only $13.4 \%$ of the total area of the canton $\left(2811 \mathrm{~km}^{2}\right)$ can be considered highly attractive" (RCT, 1990, II.11). This situation could have developed into deep social tensions between the residents and other actors interested in the property market. The significant and uncontrolled urbanisation process after the Second World War had worsened the situation and caused structural, social and environmental problems (Antonini, 1983).

Thus, the ETT's leadership in the 1980s tried to idealise tourism as a positive social phenomenon, separating it from negative outcomes such as landscape and territory

Mondes du Tourisme, $19 \mid 2021$ 
consumption - one of the most criticised aspects of tourism during the 1970s. For instance, the ETT clearly distinguished between second homeowners and tourists. Throughout the 1980s, the ETT leadership stated that the goals of tourism development and those of the residents were in line and opposed to those of speculators. Land speculation seemed to have negative effects on both the hotel sector and the residents' lifestyles. The objective of preventing such a situation arose from the very core of the ETT's understanding of tourism. E.g., from a perspective redolent of the struggle for the right to public space and reminiscent of Lefebvre's (1968) right to the city, maintaining free access to the lakesides was therefore a tourism policy that also favoured the residents. This objective demonstrates that the ETT's aim was to influence the spatial dynamics and claim a role in the process of shaping the new urban Ticino society. Contrary to the 1980s, ETT's objective in the 1990s can be described as directly opposed to the residents' desires and interests. This led to a disappearance of the political and environmental dimensions of the right to the city from the discourse. The disappearance of the topic since the 1990s makes it clear that tourism was then understood as merely economical and linked to internal elements.

\subsection{Second homes}

In the scientific literature, "second homes" have been a fascinating research object as an element of mobility, construction of homes, tourism and the appropriation of land by non-residents (Hall and Müller, 2018). Second homes are regarded as bordering tourism studies and urban planning (Müller, 2004, p. 388), but also as an expression of a mobile lifestyle (Hiltunen, 2007, p. 261). They have the social and political effects of excluding residents from the property market (Hoogendoorn and Visser, 2004). This phenomenon can also be seen as a "post-tourism" development: instead of people sojourning in tourism facilities, they build homes, potentially triggering a new urban development away from classical tourist resorts to other forms of urban places (Equipe MIT, 2011). The academic definition of second homes is therefore controversial: seen either as a specific kind of tourism or a specific kind of place-making within a "multilocal dwelling" (Stock, 2006; Blondy et al., 2018).

It is no coincidence that second homes were an important topic for ETT in the 1980s. In the second half of the $20^{\text {th }}$ century, the canton experienced a massive and rapid urban development. According to the former ETT director Marco Solari (A15), "there are not many regions in Europe that have undergone a greater transformation than Ticino". Data shows that, within an almost completely unregulated legal framework, there was a 72\% increase in the number of buildings between 1947 and 1970 (Caccia, 1984). The pressure, partially due to second homes constructed by people from Switzerland, that exerted on the property market was remarkable (Rossi, 1986). The grouping of land parcels - originally undertaken to modernise the agriculture industry - gave rise to a previously non-existent class of land speculators (Carloni, 2011).

Second homes appear to be numerous in the Alpine valleys and in non-urbanised areas as well as on the lakeside (fig. 6). In peripheral territories, the relative importance of second homes increases the weakness of such communities. Even if it is not relatively important in the urban areas under $500 \mathrm{~m}$ altitude, the phenomenon of second homes generated important territorial issues, notably the privatisation of lakeshores. The rural valleys' reduced population explains their relative importance in the 
mountainous municipalities. This imbalance increases these communities' weakness, causing rising costs in already declining peripheral municipalities.

Figure 6. Proportions of second homes to number of overall dwellings in Ticino

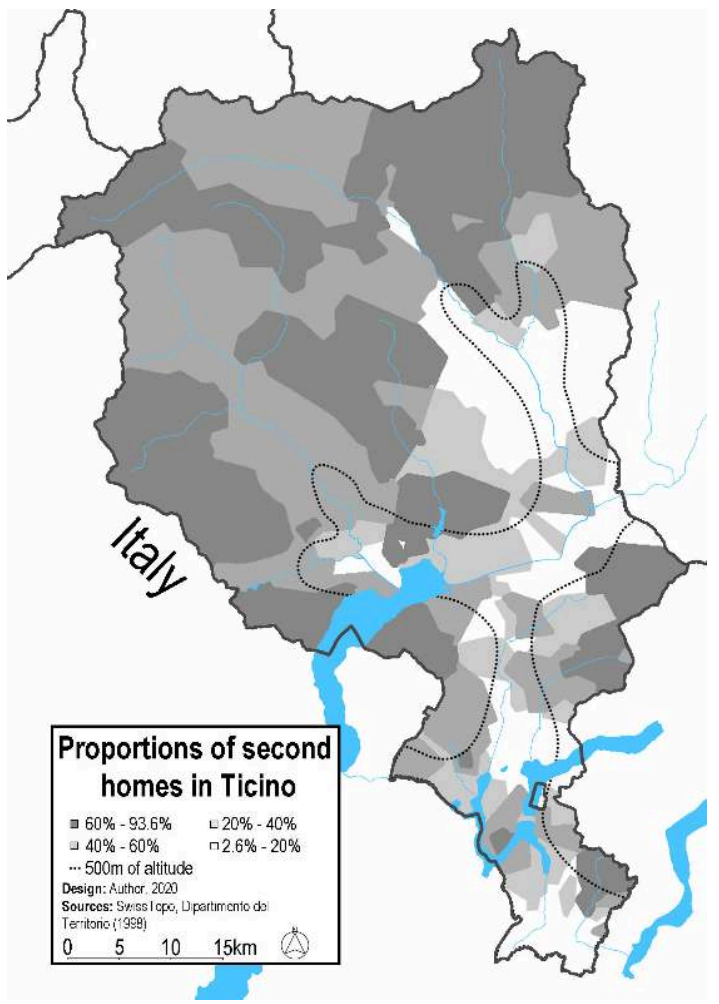

Source: Figure adapted by authors after data from RCT, 1998 1990s. The reason behind this change is the shift of ETT's understanding of its role. A new managerial perspective arose among its leadership. This transformed ETT from an important and self-conscious territorial actor - interested in favouring spatial justice to a simple lobby for hotel economic interests. However, the loss of interest in this issue by ETT leadership does not correspond to a lower incidence of second homes in public life in Ticino and Switzerland. They lie since 2012 at the heart of legal issues due to taxation, voting rights and urban development issues. In 2012, an officer of Ticino's Cantonal Statistics Bureau stated: "Currently we do not have a clear definition [of second homes] even at the cantonal level" (Cedro, 2012, p. 73). This statement followed the endorsement (by $50.6 \%$ of the voters) of the referendum "Stop the unbridled construction of second homes!" on the federal level that became lex Weber in 2015. The initiative's goal was to limit second homes to less than $20 \%$ of all the buildings in each Swiss municipality, which clearly raised the problem of legally defining a second home.

Thanks to the results of this vote we can understand how the focus of ETT's leadership has increasingly shifted away from defending the interests of the local population. While in the 1980s ETT was concerned about the overall social and territorial development of the canton, its perspective in the following decades was radically narrowed, focusing only on the hotel sector and moving away from political issues related to the territorial and tourism development of the canton. 


\section{Conclusions}

40 We have underlined the changes in the narratives of Ticino's tourism organization over the last decades. There is a clear change in the order of discourse between the 1980s and the post-1990s period, which, in turn, allows for a better understanding of the transition from a rural to an urban society. We interpret it as a movement from a Keynesian and developmental rationality to a neoliberal one. The main feature of this case is the speed with which this transition took place over the course of a few years. This is a radical change in the way tourism is conceived on a cantonal scale.

41 At first, the ETT discourse was focused on a global understanding of the tourism phenomenon as a part of social and political life. The ETT repeatedly underlined this interrelation. Owing to the hotel sector crisis and the change in the directorate in the 1990s, there was a sudden shift towards a new managerial perspective that only considered tourism as an economic sector. The new ETT goals were therefore linked to the sole hotel sector, disregarding the broader connections with Ticino's urban reality. This change denoted the transformation of the public actor's objectives from achieving a balance between urban and tourism development, to lobbying for the private hotel sector. Also, it exemplifies a more important transition in governance models towards what we call the neoliberalism paradigm (Foucault, 2008). In this new situation, state intervention in tourism was simply justified as increasing private gains - as shown by the later transition from a public-owned ETT to a public-private partnership ATT - and only indirectly justified as favouring the residents' economic status and a more inclusive urban setting. The evolution from a spatial justice ideal towards a purely economic neoliberal approach, to tourism management, implies a conception that widely regards inhabitants' interests as meaningless. The centralisation of tourism organisations around urban centres (fig. 4) is a further example of the abandonment of a policy of territorial balance. This evolution led to a disconnection between tourism as a social problem, which raises issues of spatial justice, stereotypes and economical dimensions, and tourism as a mere economic problem. This reductionist institutional framing seems to be one of the major problems that urban societies currently face.

This paper aims to contribute to the literature on tourism and regional development by understanding tourism as linked to urbanisation processes. Whether in resort development or regional development, this issue is frequently overlooked because of a narrow definition of the urban as only concerning city (Coëffé and Stock, 2021). We contend tourism is per definition an urban issue, yet often taking a different territorial form than the morphologically recognized form of the city. This empirical case highlights the importance of a critical analysis of tourism as a way to better understand the ongoing planetary urbanisation and its discursive governance. The analysis of tourism discourse evolution shows a transformation in the way institutions understand urban reality. This does not necessarily suggest a strong causal link between tourism discourses and urban processes. However, second homes, rustici, centralisation, etc. are all indicators of an urban transition and of an urban society. Analysing these aspects is an important step, both for tourism and for urban studies.

Indeed, urban issues seem crucial in tourism studies. Questions about the accessibility of lakesides, the development of peripheral valleys and the fight against second home proliferation denote the ETT leadership's clear awareness of tourism's urban dimension - that is, the way in which tourism contributes to produce and transform urban spaces. 
Yet the question of spatial justice is never raised in the 1990s. The following questions seem crucial to fully grasp the effects of tourism today. What role do residents' interests play in tourism development? Will the population accept the cantonal authorities' reductionist perspective, or will the residents turn against the tourists? These questions are especially important in the light of the current anti-tourism and so-called "overtourism" movements, which seem to be indicators of the urgent need to think about the production of space through tourism.

\section{BIBLIOGRAPHY}

Sheela AGARWAL, "Restructuring Seaside Tourism: The Resort Lifecyle", Annals of Tourism Research, vol. $29, \mathrm{n}^{\circ} 1$, p. 25-55, 2002.

Michel AGLIETTA, A Theory of Capitalist Regulation, New Left Books, 1979.

Benedetto ANTONINI, "Principi operativi e metodo di lavoro del Piano direttore del Canton Ticino", Rivista Tecnica, n 5, p. 84-90, 1983.

Caroline Blondy, Christine Plumejeaud, Luc Vacher, Didier vye and Caroline Bontet, "Do Second Home Owners Only Play a Secondary Role in Coastal Territories?", in Colin Michael Hall and Dieter Müller (eds), The Routledge Handbook of Second Home Tourism and Mobilities, Routledge, 2018.

Robert BOYER, The Regulation School: A Critical Introduction, Columbia University Press, 1990.

Neil BRENNER and Christian SCHMID, “The 'Urban Age' in Question”, International Journal of Urban and Regional Research, vol. 38, n 3, p. 731-755, 2014 [https://onlinelibrary.wiley.com/doi/abs/ 10.1111/1468-2427.12115].

Stephen BRITTON, “Tourism, Capital, and Place: Towards a Critical Geography of Tourism”, Environment and Planning: Society and Space, $\mathrm{n}^{\circ}$ 9, p. 451-478, 1991.

Fulvio CACCIA, “Costruzioni fuori dalle zone edificabili”, Rivista Tecnica, n 10, p. 54-56, 1984.

Tita CARLONI, Pathopolis, Casagrande, 2011.

Lorenzo CEDRO, "Di cosa parliamo quando parliamo di residenze secondarie?", Dati. Statistiche e società, XII, p. 73-75, 2012.

Raffaello CESCHI, "Il territorio e gli abitanti”, in Raffaello Ceschi (ed.), Storia del Cantone Ticino [History of Canton Ticino], Stato del Cantone Ticino, 1998, vol. I, p. 15-32.

Raffaello CESCHI and Andrea GHIRINGHELLI, "Dall'intesa di sinistra al governo quadripartito (1947-1995)”, in Raffaello CESCHI (ed.), Storia del Cantone Ticino, Stato del Cantone Ticino, 1998, vol. II, p. 551-576.

Vincent COËFFÉ and Mathis STOCK, “Tourism as Urban Phenomenon and the Crux of 'Urban Tourism”, in Mathis Stock (ed.) Progress in French Tourism Geographies. Inhabiting Touristic Worlds, Springer, 2021 [https://doi.org/10.1007/978-3-030-52136-3_11]. 
Tim COLES, “A Local Reading of a Global Disaster: Some Lessons on Tourism Management from an Annus Horribilis in Southwest England", Journal of Travel and Tourism Marketing, vol. 15, $\mathrm{n}^{\circ}$ 2/3, p. 143-162, 2003 [https://www.tandfonline.com/doi/abs/10.1300/J073v15n02_10].

Frédéric DARBELLAY and Mathis STOCK, “Tourism as Complex Interdisciplinary Research Object", Annals of Tourism Research, vol. 39, n 1, p. 441-458, 2012 [https://www.sciencedirect.com/science/ article/abs/pii/s0160738311001149].

Roger DIENER, Jacques HERzoG, Marcel MEILI, Pierre DE MEURON and Christian SCHMID, Switzerland. An Urban Portrait, Birkhäuser, 2006.

EQUIPE MIT, Tourismes 1. Lieux communs, Belin, 2002.

EQUIPE MIT, Tourismes 3. La révolution durable, Belin, 2011.

Norman fAIRCLOUGH, "The Dialectics of Discourse", Textus, n 14, p. 231-242, 2001.

Michel foucault, The Birth of Biopolitics: Lectures at the Collège de France 1978-1979, Palgrave, 2008.

Henning FÜLLER and Boris MICHEL, “'Stop Being a Tourist!' New Dynamics of Urban Tourism in Berlin-Kreuzberg”, International Journal of Urban and Regional Research, vol. 38, n 4, p. 1304-1318, 2014 [https://doi.org/10.1111/1468-2427.12124].

Luz Marina García herRera, Neil SMIth and Miguel Ángel mejíAs Vera, “Gentrification, Displacement, and Tourism in Santa Cruz De Tenerife", Urban Geography, vol. 28, n 3, p. 276-298, 2007 [https://www.tandfonline.com/doi/abs/10.2747/0272-3638.28.3.276].

Andrea GHIRINGHELLI, “La costruzione del Cantone (1803-1830)”, in Raffaello Ceschi (ed.), Storia del Cantone Ticino, Stato del Cantone Ticino, 1998, vol. I, p. 33-62.

Antonio GRAMSCI, Prison Notebooks, Columbia University Press, 2011.

Maria GRAVARI-BARBAS and Sandra GUINAND, Tourism and Gentrification in Contemporary Metropolises. International Perspectives, Routledge, 2017.

Maarten A. HAJER, The Politics of Environmental Discourse: Ecological Modernization and the Policy Process, Oxford Scholarship Online, 2003.

Colin Michael HALL and Dieter MÜLLER (eds), The Routledge Handbook of Second Home Tourism and Mobilities, Routledge, 2018.

David HARVEY, “The Right to the City”, New Left Review, n53, p. 23-40, 2008.

David HARVEY, Spaces of Capital. Towards a Critical Geography, Routledge, 2001.

Donald E. HAWKINS and Shaun MANN, "The World Bank's Role in Tourism Development", Annals of Tourism Research, vol. 34, n² 2, p. 348-363, 2007.

Mervi J. HILTUNEN, "Environmental Impacts of Rural Second Home Tourism. Case Lake District in Finland”, Scandinavian Journal of Hospitality and Tourism, vol. 7, n 3, p. 243-265, 2007.

Lily M. HOFFMAN, Susan S. FAINSTEIN and Dennis R. JUDD (eds), Cities and Visitors: Regulating People, Markets, and City Space, Blackwell, 2003.

Gijsbert HOOGENDOORN and Gustav VISSER, "Second Homes and Small-Town (Re)Development: The Case of Clarens", Journal of Family Ecology and Consumer Sciences, n 32, p. 105-115, 2004.

Cédric HUMAIR, Marc GIGASE, Julie LAPOINTE GUIGOZ and Stefano SULMONI, Système touristique et culture technique dans l'Arc lémanique. Analyse d'une success story et de ses effets sur l'économie régionale (1852-1914), Alphil/Presses universitaires suisses, 2014. 
Florian KOHLBACHER, “The Use of Qualitative Content Analysis in Case Study Research”, Forum: Qualitative Social Research, vol. 7, n 1, 2006 [https://www.qualitative-research.net/index.php/fqs/ article/view/75].

Jost KRIPPENDORF, Die Landschaftsfresser, Hallwag, 1977.

Henri LEFEBVRE, Du rural à l'urbain, Anthropos, 2001.

Henri LEFEBVRE, La production de l'espace, Anthropos, 2000.

Henri LEFEBVRE, La révolution urbaine, Gallimard, 1970.

Henri LEFEBVRE, Le droit à la ville, Anthropos, 1968.

Dean Maccannell, “Tourist Agency”, Tourist Studies, vol. 1, n 1, p. 23-37, 2001 [https:// journals.sagepub.com/doi/10.1177/146879760100100102].

Dean MACCANNELL, The Tourist: A New Theory of the Leisure Class, Schocken, 1999.

Clément MARIE DIT CHIROT, “Towards a Political Economy of Tourism. Reflections on Latin American Case Studies", Norois, n 247, 2018 [https://doi.org/10.4000/norois.6421].

Diego MEDICI, Roberto STOPPA and Ursula RÜTTER-FISCHBACHER, L'impatto economico del turismo in Ticino, 2014 [https://www.mendrisiottoturismo.ch/en/dam/jcr:61d5a9c2-4f7f-49f6af46-633b7e3301a0/2014\%20-\%20r\%C3\%BCtter\%20soceco\%20\%20L\%27impatto\%20economico\%20del\%20turismo\%20in\%20Ticino.pdf].

Patrick MULLINS, “Tourism Urbanization”, International Journal of Urban and Regional Research, vol. 15, n 3, p. 326-342, 1991 [https://onlinelibrary.wiley.com/doi/10.1111/j.

1468-2427.1991.tb00642.x].

Dieter K. MÜLLER, "Mobility, Tourism and Second Homes", in Alan Lew, Michael C. Hall and Allan M. Williams (eds), A Companion to Tourism, Blackwell, 2004, p. 387-398.

REPUBBLICA E CANTONE TICINO, Legge sullo sviluppo territoriale, 2011 [https://m3.ti.ch/CAN/RLeggi/ public/index.php/raccolta-leggi/legge/num/398].

REPUBbliCA E CANTONE TICINO, Revisione del Piano Direttore Cantonale. Rapporto esplicativo, 2009.

REPUBBLICA E CANTONE TICINO, 245 Comuni alla lente, 1998.

RePubblica e Cantone ticino, Progetto di Piano Direttore Cantonale, 1990.

Bruno REICHLIN and Fabio REINHART, "Introduzione", in Aldo Rossi, Eraldo Consolascio and Max Bosshard (eds), Costruzione del territorio e spazio urbano nel Cantone Ticino, Fondazione Ticino Nostro, 1979.

Angelo RossI, “La regione funzionale urbana di Lugano”, Rivista Tecnica, n 11, p. 43-52, 1986.

Aldo ROSSI, Eraldo CONSOLASCIO and Max BOSSHARD (eds), Costruzione del territorio e spazio urbano nel Cantone Ticino, Fondazione Ticino Nostro, 1979.

Jarkko SAARINEN and Tiit KASK, "Transforming Tourism Spaces in Changing Socio-Political Contexts: The Case of Pärnu, Estonia, as a Tourist Destination”, Tourism Geographies, $\mathrm{n}^{\circ} 10$, p. 452-473, 2008 [https://www.tandfonline.com/doi/abs/10.1080/14616680802434072].

Julie scotT and Tom SELWYN, Thinking Through Tourism, Berg, 2010.

John SOANE, Fashionable Resort Regions: Their Evolution and Transformation. With Particular Reference to Bournemouth, Nice, Los Angeles and Wiesbaden, CAB International, 1993. 
Edward soJA, Thirdspace: Journeys to Los Angeles and Other Real-and-Imagined Places, Blackwell, 1996.

Mathis sтоск, "Inhabiting the City as Tourist. Issues for Urban and Tourism Theory", in T. Frisch, C. Sommer, L. Stoltenberg and N. Stors, Tourism and Everyday life in the Contemporary City, Routledge, 2019, p. 42-66.

Mathis Sтоск, "L'hypothèse de l'habiter polytopique : pratiquer les lieux géographiques dans les sociétés à individus mobiles", Espacestemps.net, 2006 [https://www.espacestemps.net/articles/ hypothese-habiter-polytopique/].

Mathis STOCK, Christophe CLIVAz, Olivier CREVOISIER, Leila KEBIR and Stéphane NAHRATH, Resort Development and Touristic Capital of Place, Université de Neuchâtel, 2014 [https://www.unine.ch/ files/live/sites/maps/files/shared/documents/wp/WP_5_2014_MS_et_al\%20(2).pdf].

Mathis Бтоск and Léopold LUCAS, "La double révolution urbaine du tourisme", Espaces et sociétés, vol. 3, n 151, p. 15-30, 2012.

Nadira TALIB and Richard FITZGERALD, "Putting Philosophy Back to Work in Critical Discourse Analysis", Critical Discourse Studies, 2018 [https://www.tandfonline.com/doi/abs/ 10.1080/17405904.2017.1421242].

Sandra TAYLOR, "Researching Educational Policy and Change in 'New Times': Using Critical Discourse Analysis", Journal of Education Policy, vol. 19, n 4, p. 433-451, 2004 [https:// www.tandfonline.com/doi/abs/10.1080/0268093042000227483].

Laurent TISSOT, Naissance d'une industrie touristique, Payot, 2000.

UNWTO, Compendium of Tourism Statistics. Data 2014-2018, United Nations World Tourism Organization, 2020 [https://www.e-unwto.org/doi/book/10.18111/9789284421459].

John URRY, The Tourist Gaze: Leisure and Travel in Contemporary Societies, Sage, 1990.

John K. WALTON, The English Seaside Resort. A Social History 1750-1914, Leicester University Press, 1983.

Allan M. WILLIAMS and Gareth SHAW, Tourism and Tourism Spaces, Sage, 2004.

\section{ABSTRACTS}

Mass tourism is a fundamental phenomenon of the second half of the 20th century, and contributes to urbanisation processes. In order to uncover the evolution of the institutional perspective on urban issues, we mobilise two main conceptual tools: the regulation of capitalism, and the production of space through tourism. Our paper positions itself as an example of "thinking through tourism", where tourism is used as a means of analysing social change rather than as an object in itself. We ask how institutional discursive destination construction has changed in the Swiss canton of Ticino between the1980s and the 2010s. Our results show a progressive change towards a merely economic and hotel-centred understanding of tourism governance over this period. It exemplifies an increasingly economic and sectoral vision, which abandons a more organic understanding of the touristic phenomenon and neglects its social role. It is an exemplary case of institutional neoliberalisation.

Le tourisme de masse est un phénomène fondamental de la seconde moitié $\mathrm{du} \mathrm{xx}^{\mathrm{e}}$ siècle et contribue aux processus d'urbanisation. Afin de découvrir l'évolution de la perspective institutionnelle sur les questions urbaines, nous mobilisons deux principaux outils conceptuels : la régulation du capitalisme et la production d'espace par le tourisme. Notre article se positionne 
comme un exemple de "penser par et avec le tourisme ", où le tourisme est utilisé comme un moyen d'analyse du changement social plutôt que comme un objet en soi. Nous nous demandons comment la construction discursive d'une destination par les institutions a changé dans le canton du Tessin entre les années 1980 et 2010. Nos résultats montrent un changement progressif vers une conception de la gouvernance du tourisme simplement économique et centrée sur l'hôtellerie au cours de cette période. Ils illustrent une vision de plus en plus économique et sectorielle, qui abandonne une conception plus organique du phénomène touristique et néglige son rôle social. Il s'agit d'un cas exemplaire de néolibéralisation institutionnelle.

\section{INDEX}

Mots-clés: destination touristique, Tessin, capitalisme, urbanisation, analyse du discours, gouvernance du tourisme, Suisse

Keywords: tourist destination, Ticino, capitalism, urbanisation, discourse analysis, tourism governance, Switzerland

\section{AUTHORS}

\section{MOSÈ COMETTA}

$\mathrm{PhD}$ in Geography,

Post-doc researcher, Università degli Studi di Torino

https://orcid.org/0000-0001-8700-2030

mose.cometta[at]unito.it

\section{MATHIS STOCK}

Professor,

Institute of Geography and Sustainability, Université de Lausanne

mathis.stock[at]unil.ch 